\title{
Immigrant integration: the governance of ethno-cultural differences
}

\author{
Leila Hadj Abdou
}

Correspondence:

leila.hadj-abdou@eui.eu Migration Policy Center, Robert

Schuman Centre for Advanced

Studies, European University

Institute (EUI), Florence, Italy

\begin{abstract}
This commentary is a reply to the article 'Against immigrant integration' by Willem Schinkel. It argues that rather than abandoning immigrant integration as a field of research, we have to continue to strengthen critical approaches. Immigrant integration has to be understood and analyzed as a governance technique, rendering differences purposeful for certain ends. In this way, categories such as class and race get into the picture instead of being omitted. It is also emphasized that we have to look beyond the nation state to truly unsettle common sense ideas about immigrant integration and the migrant 'other'. These points are illustrated by discussing the 'management' of immigrant integration in cities in Europe.
\end{abstract}

Keywords: Immigrant Integration, Cities, Diversity, Political Economy

\section{Shifting perspectives: focusing on governance $\&$ beyond the national}

This contribution is a reply to the article 'Against immigrant integration' by the sociologist Willem Schinkel. Schinkel's critique of immigrant integration research as a neo-colonial knowledge production project is in many ways spot-on; his contribution however, falls short in providing a discussion of productive ways out of this problematic research path. Schinkel's key point is that the social science of immigrant integration plays a crucial part in problematizing the migrant 'other', by providing the "factual architecture of this problematization" (Schinkel, 2018). Schinkel therefore-and herein lies the relevance of his claim-argues that immigrant integration researchers are not only doing poor research by adopting analytically flawed concepts such as integration, but they become accomplices in a neo-colonial system of oppression. If we accept Schinkel's criticism, the question we have to tackle is: how can we put an end to or reverse this complicity? Schinkel notes that, for a start, any claim and practice that concerns integration should be the object of research, rather than the project of research. Following this line of thought, I argue in this contribution that rather than abandoning immigrant integration as a field of research, we have to turn around the telescope. Immigrant integration has to be understood and approached as a phenomenon that reveals more about those who articulate ideas about integration and decide on integration measures than it does about those who are the target of integration (i.e. the migrant 'other'). In a nutshell, the key proposal I am making is that immigrant integration should be conceptualized and approached as a governance technique rendering ethno-cultural differences purposeful for certain ends. This technique and its varying

(c) The Author(s). 2019 Open Access This article is distributed under the terms of the Creative Commons Attribution 4.0 International License (http://creativecommons.org/licenses/by/4.0/), which permits unrestricted use, distribution, and reproduction in any medium, provided you give appropriate credit to the original author(s) and the source, provide a link to the Creative Commons license, and indicate if changes were made. 
purposes can be traced analytically in discourses, practices, regulations, and institutions.

We, moreover, have to look beyond the nation state to truly unsettle common sense ideas about immigrant integration, and to understand the various underlying ends of immigrant integration projects. It is the understanding of these underlying purposes that, in turn, will enable us to make critical judgments about immigrant integration, providing one possible alternative path to the current complicity Schinkel is highlighting. To make these considerations more tangible, I will illustrate my points by discussing the 'management' of immigrant integration at the city level.

Shifting the focus beyond the national though, is not to deny the decision-making power and potency of nation states. Despite continuing globalization and regionalization processes, and the existence of transnational spaces and actors, the nation state undoubtedly remains an important category that structures the mindset of decision-makers and provides a sense of belonging for many people (Glick Schiller \& Wimmer, 2002, p. 326). Recent developments in which the immigration issue has played a key role, such as Brexit in the heart of a highly regionalized Europe, and the rise of nationalist political party currents in liberal Western democracies, leave no doubt about this potency of the nation state and the mobilizing power of national identities.

At the same time, other polities such as the sub-national one do matter. Immigration is to a large extent an urban phenomenon, and immigrant integration has been viewed more and more as a local government task. City governments have become major players in immigrant integration, a fact that is increasingly being recognized by migration scholars (Adam \& Caponio, 2018; Zapata-Barrero, Caponio, \& Scholten, 2017). Recently, local authorities have also gained agency in the conceptualization and the execution of immigration-related tasks (Thouez, 2018). Simply put, local, city governments are decisive in shaping and regulating immigration and immigrant integration, which deserves scholarly attention. If migration and integration research has the ambition to confront 'methodological nationalism', i.e. the assumption that the nation state is the natural social and political formation of the modern world (Glick Schiller \& Wimmer, 2002, p. 302), it is imperative to look at processes and dynamics beyond the nation state.

\section{The need for critical approaches}

In order to substantiate my main argument about the necessity to turn the telescope and to focus on integration as a governance technique, I will now discuss the need for more critical approaches in immigrant integration studies. My aim in this section is to complement Schinkel's perspectives and add a partly different reading of the underlying problems integration research is faced with.

At this point, let me clarify what I mean when I refer to the term 'critical'. Adopting a critical approach is not simply about saying that things are not right, as Foucault (1988, p. 154) famously noted. It is rather about pointing out what kind of assumptions and premises, what kinds of familiar, unchallenged, unconsidered mode of thoughts, accepted practices, and ways of seeing things are based on (Foucault, 1988, p. 154). Simplified, it could be said that critique implies the challenging of common sense categories and ideas, which are established and reproduced through relations of power. 
On the other hand, being uncritical involves an act of depoliticization, taking power relations and asymmetries out of the picture.

The claim that critical approaches are not necessarily the default mode in migration and integration research, is a valid argument made by Schinkel. This lack of critical approaches is related to the fact that the very existence of migration and integration research is rooted in the naturalized citizen/migrant binary of modern nation states. This binary translates in everyday practices and discourses into an 'us' versus 'them' schemata, in which the 'us' represents the underlying unquestioned, and thus unproblematized, norm. To be an immigrant as opposed to a national citizen "is a displaced presence in every sense of the term" as the sociologist Sayad (2004, p. 283) so elegantly reminds us in his work 'The Suffering of the Immigrant'. Migration research is constituted by this politically constructed logic of migration as anomaly. Without it, there would be nothing such as migration and immigrant integration studies (Dahinden, 2016, p. 2210).

This crucial point has been discussed by migration scholars for quite some time now. Let us also recall that leading migration and immigrant integration scholars (e.g. Favell, 2003) have continuously questioned the analytical value of concepts such as immigrant integration and have reminded us that differences are constitutive of the social fabric. Joppke and Morawska (2003, p. 3), for example, have emphasized more than a decade ago that an integrated 'society' does not exist anywhere, except in the imagination of some (especially political) actors.

This is not to say that there is no need for the kind of arguments made by Schinkel any more. Despite a long-standing critical debate which has undoubtedly stimulated the field in meaningful ways (Amelina, 2017), reflections on the implications of this criticism, and research practices that take these implications fully into account are still limited. These limitations are partly related to conditions external to academia, such as the increasing pressure on academia to inform policy making, which supports the adoption and reproduction rather than the questioning of preset perspectives. But these limitations are certainly also rooted within the development of the research field. As Schinkel (2018) emphasizes, migration and immigrant integration research have become somewhat detached from larger social science debates. Schinkel (2018) took note of the tendency to disregard the rich scholarship in areas such as critical race or postcolonial studies, which has resulted in a relative scarcity of debates on processes of racialization and racism in the immigrant integration research field. In addition, I would like to emphasize that considerations of the political economy and shifts in production, too, have been largely absent from analytical accounts in the field (cf. Menz, 2013, p. 112; Hiebert, Rath, \& Vertovec, 2015, p. 7). This lack of political economy perspectives in turn accounts for a shortage of reflections on class dynamics. A similar argument can be made for gender and sexuality. Although gender and sexuality informed perspectives have definitely gained visibility in migration and integration research, overall, they are still far from the spotlight (cf. Korteweg, 2017). Categories such as class, race, sex and gender are, however, of utmost importance if we want to move beyond common sense understandings of 'the' migrant and migrants' experiences.

Another major reason for the relative lack of critical studies is related to a specific bias of immigrant integration scholars as regards the political program of immigrant integration. The widespread idea that immigrant integration is first and foremost about 
enabling migrants to have a better position in their respective society of settlement (Mahnig, 2001, p. 125) is a common belief among integration scholars, which consequently also motivates much of the research in the field. Immigrant integration research largely understands itself as supporting this (presumably) pro-migrant political program.

However, integration in itself is not a political program. Conversely, it is and always has been an extremely vague concept. It is exactly its looseness, and the extensibility of the concept 'integration', that renders it (politically) successful (Mahnig, 2001, p. 127), and also makes the concept so sticky despite repeated waves of criticism brought by scholars and anti-racist (migrant) activists (Waters, 2018).

The vast amount of European migration research that challenges political programs in the domain of immigration (control) (e.g. Anderson, 2016 just to name one among many) holds no comparison with volume of similar endeavors in the sub-field of immigrant integration research. In a provocative manner, let me call this the pro-immigrant political inclination of migration (control) research. It is the very same pro-immigrant inclination, however, which manifests itself in the relative lack of critical approaches found in the field of immigrant integration.

The common understanding of immigrant integration as 'desirable', obstructs the view on the various, complex ends of immigrant integration as a political program, and renders migration scholarship related to immigrant integration less critical.

Allow me a last thought, which specifically attempts to account for the lack of critical approaches in the quickly growing and increasingly popular sub-field of immigrant integration studies (which is also at the core of this contribution), namely, local integration studies. There has been a tendency in this strand of scholarship to describe the city level either as a 'diversity-friendly' arena (e.g. Penninx, 2009; Gesemann \& Roth, 2009; Guiraudon, 2009; Vertovec, 1996; Vertovec \& Wessendorf, 2010, p. 31), or as an arena governed by pragmatic actors who have to deal with problems of integration on the ground (e.g. Gebhardt, 2014). City polities indeed potentially differ from nation states. The nation state and national citizenship are institutions based on principles of social closure. While rights and resources are widely accessible to members, this is not necessarily the case for others. In contrast, in modern cities (as opposed to previous city polities throughout history) membership is relatively open. One becomes a member by residence; one loses membership automatically by relinquishing residence (Bauböck, 2003). "People vote with their feet, joining or leaving is a matter of moving" (Soehl, 2008). While we need to acknowledge that cities and city governments, in contrast to nation states, are potentially more predisposed to openness towards 'strangers', integration research needs to dig deeper. If we want to develop a critical account, the concrete ends of local immigrant integration need to come into focus. Immigrant integration research can benefit here from the extremely rich tradition of critical scholarship in urban studies dating back to the works of scholars such as Lefebvre (1968).

Developing critical approaches should not be an end in itself though. Critique for the sake of critique seems to be a pointless effort. So, let us recall again what the merits of such a critical approach to immigrant integration are. One point that is often forgotten, and that I therefore want to single out here is the following: The problem of immigrant integration is not only a problem for those who are 'problematized, and for whose problematization immigrant integration studies provide the 'factual architecture', to use 
Schinkel's phrasing again. It also does a disfavor to those who are not 'problematized', who are constructed as being inside this 'integrated society'. In other words, as a result of the imagination of an integrated society, existent inequalities and different political interests within this 'society' can become concealed and sidelined. It is eventually this sidelining of differences and the downplaying of existing inequalities within the imagined integrated society that facilitates the 'native' opposition to the migrant 'other' (see e.g. Rooduijn \& Burgoon, 2017).

\section{Immigrant integration in the post-Fordist city}

As noted before, immigrant integration is increasingly becoming a core concern of city governments. Often the approach to immigration, and consequently also to integration, seems to be actually diverging with, or even opposing, national governments' positions (Gebhardt, 2014). Let's take the illustrative example of London as such a contradicting positioning. In the wake of the Brexit referendum, London's Mayor Sadiq Khan has launched the campaign \#LondonIsOpen, reflecting the city's concern with the referendum vote, and the support for a 'multicultural' London open to immigration and diversity: "[the campaign] reassures the more than one million foreign nationals who live in London that they will always be welcome, and that any form of discrimination will not be tolerated" (Government of London, 2018).

The city's commitment to immigration and diversity is not a specificity of the current local Labour government, or an attempt to delineate the locally ruling Labour party from the nationally governing Conservative Party. Previous mayors of London have also adopted immigration, endorsing positions that were in contrast to the more control-oriented approach of national government. For instance, during his time in office, the conservative mayor Boris Johnson, who later would become one of the chief advocates for Brexit in national government, firmly opposed national government plans to cut down on immigration (Hadj Abdou \& Geddes, 2017). This opposition does not come as a surprise, considered the global economic hub London is. The strong economic position of the city is also related to the fact that it is a cultural hub too, with a prospering creative industry, which relies on diversity, free movement and international supply chains. To put it bluntly, openness to diversity and immigration are seen as key factors of the economic strength of the city.

The fact that ethno-cultural diversity is understood, and consequently also promoted, as a competitive advantage for cities in an environment of globalized markets has also become a widespread phenomenon beyond global cities such as London. Increasingly, mid and small-sized cities across Europe are conceptualizing immigration and diversity as essential for economic growth. This in turn has stimulated the adoption of similar immigrant integration policy approaches by local governments across European cities (Hadj Abdou, 2014, Hadj Abdou \& Geddes, 2017). Intercultural or diversity policies, i.e. approaches that promote openness, exchange and encounter, have gained foothold. These policies attempt (among other ends) to harness ethno-cultural diversity for economic gains. Diversity, if managed well through immigrant integration, is seen as an opportunity to create and foster an image of the city, which makes it attractive for foreign investment, tourism, and increased consumption. The encounter and cooperation between people from diverse backgrounds is, moreover, viewed by local government 
and other key governance actors as essential for the production of creativity and innovation (see e.g. Council of Europe, 2015).

Official positions and immigrant integration policies, thus, cannot be fully understood without taking into account political economy dynamics. The increasing tendency to see diversity as an asset to be supported and promoted through respective integration measures has been a specific feature of post-Fordist knowledge economies. In a nutshell, in the Fordist industrial economy, cities functioned as a symbol of the nation and tended to feature processes of de-ethnicization and cultural assimilation (Kaltmeier, 2011, p. 93). By contrast, in Post-Fordism diversity is used to stimulate urban economic development (Kaltmeier, 2011, p. 96). Cities have become somewhat detached from nation states. Economic competition, formerly played out between nation states, in today's globalized economy more often takes place directly between cities. This detachment of cities from nation states partly explains the growing role, and the often distinct if not opposing position, of local governments relative to their national counterparts regarding immigration.

The 'openness to diversity and immigration' discourses and practices that these developments are manifested in, however, are not without implications for urban inequalities. On the contrary, these discourses and practices, as the rich and growing field of contemporary critical urban studies shows, tend to reproduce and reorganize 'race' in the city through processes of racialization and a re-making of the racial subject (see e.g. Almeida, 2016). Diversity becomes commodified. 'Only those who have the class, cash, and right ethnicity can enjoy the rewards and benefits of diversity' (Shaw, 2007, cit. after Almeida, 2016, p. 104). 'Openness' discourses and practices thus apply selectively to certain voices and experiences, as they are directed 'to those who can afford it' (Georgiou, 2017, p. 25). While these discourses draw on the values of openness and hospitality, they are part of a project that often negates these very values when it comes to collective sharing of the city's resources (Georgiou, 2017). It is an "ethics of respect without recognition" as Georgiou (2017) notes, for instance, for the case of London. Racialized and classed constellations in the urban knowledge economy are often obscured and remade in the neoliberal, diverse city.

In sum, while cities and their governments are not only more predisposed to openness to 'strangers' but are also often committed to this openness in their rhetoric and their policies, this 'openness' might actually be constituted by, and based upon, inequalities.

\section{Concluding remarks}

I have used the example of immigrant integration in cities as an illustration for a possible critical perspective in immigrant integration research, as an avenue to look beyond the nation state, and to bring categories such as race and class into the picture, rather than omitting them by taking 'the' migrant as the key analytical category.

The overall approach I advocated for is conceptualizing immigrant integration as a governance technique. I have argued that the interesting and relevant question to ask is: which ends do governments, and more broadly, governance actors, have in mind when they 'manage' integration? In the neo-liberal city-as I have discussed-immigrant integration is about the stimulation of economic growth. 
The governance technique of immigrant integration does not emerge in a void. Policies and practices of integration involve a "way of knowing' or getting to know who immigrants are and 'how to recognize the problem"' (Gray, 2006, p. 121). Research, as Schinkel's important work is emphasizing, holds a fundamental role in 'getting to know'. Therefore, we do not only need to promote a turning of the telescope to focus more on governance, but as a part of this shift of perspective, we have to continue, unapologetically of our own complicity, to make an effort to understand how knowledge is produced, disciplined and practiced in migration and immigrant integration research.

\section{Author's contribution}

LHA wrote this manuscript. The author read and approved the final manuscript.

\section{Competing interests}

The author declares that she has no competing interests.

\section{Publisher's Note}

Springer Nature remains neutral with regard to jurisdictional claims in published maps and institutional affiliations.

Received: 30 August 2018 Accepted: 19 October 2018

Published online: 30 April 2019

\section{References}

Adam, I., \& Caponio, T. (2018). Research on the multi-level governance of migration and migrant integration. Reversed pyramids. In A. Weinar, S. Bonjour, \& L. Zhynormirska (Eds.), Routledge handbook of the politics of migration in Europe, (pp. 26-37). London: Routledge.

Almeida, S. (2016). Exposing the threads: a critical interrogation of the policies, practices and (non-)performativity of diversity in the City of Toronto. Wagadu: A Journal of Transnational Women's and Gender Studies, 16, 94-123.

Amelina, A. (2017). After the Reflexive Turn in Migration Studies: Towards the Doing Migration Approach. Goethe University Working Paper Series "Gender, Diversity and Migration" No. 13.

Anderson, R. (2016). Europe's failed 'fight' against irregular migration: ethnographic notes on a counterproductive industry. Journal of Ethnic and Migration Studies, 42(7), 1055-1075.

Bauböck, R. (2003). Reinventing urban citizenship. Citizenship Studies, 7(2), 139-160.

Council of Europe. (2015). Intercultural Cities Program (ICC). Retrieved 6 March, 2017 http://www.coe.int/t/dg4/cultureheritage/ culture/cities/default_en.asp.

Dahinden, J. (2016). A plea for the 'de-migranticization' of research on migration and integration. Ethnic and Racial Studies, $39(13), 2207-2225$

Favell, A. (2003). Integration nations: the nation-state and research on immigrants in Western Europe. Comparative Social Research, 22, 13-42.

Foucault, M. (1988). Practicing criticism. In L. D. Kritzman (Ed.), Politics, philosophy, culture: interviews and other writings, $1977-$ 1984, (pp. 152-158). New York: Routledge.

Gebhardt, D. (2014). Building Inclusive Cities: Challenges in the Multilevel Governance of Immigrant Integration in Europe. Washington D.C.: Migration Policy Institute.

Georgiou, M. (2017). Is London open? Mediating and ordering cosmopolitanism in crisis. International Communication Gazette, 79(6-7), 636-655

Gesemann, F., \& Roth, R. (2009). Lokale Integrationspolitik in der Einwanderungsgesellschaft [Local integration policy in the immigration society]. Wiesbaden: Springer.

Glick Schiller, N., \& Wimmer, A. (2002). Methodological nationalism and beyond. Nation-state building, migration and the social sciences. Global Networks, 2(4), 301-334.

Government of London (2018). Our \#London/sOpen campaign. Retrieved 26 July, 2018 from https://www.london.gov.uk/ about-us/mayor-london/londonisopen

Gray, B. (2006). Migrant integration policy. A nationalist fantasy of management and control? Translocations, 13(1), 121-141.

Guiraudon, V. (2009). The multi-level governance of international migration. An unbalanced act?. Presentation at the Committee of the Regions Atelier, "Multi-level governance in the EU: New prospects for a European Union with its regions and cities", October 7, 2009, Brussels.

Hadj Abdou, L. (2014). Revising the immigrant integration agenda in the city: a comparison of political responses to ethnocultural diversity in Dublin and Vienna. Journal of Ethnic and Migration Studies, 40(12), 1875-1894.

Hadj Abdou, L., \& Geddes, A. (2017). Managing superdiversity? Examining the intercultural policy turn in Europe. Policy \& Politics, 45(4), 493-510

Hiebert, D., Rath, J., \& Vertovec, S. (2015). Urban markets and diversity: Towards a research agenda. Ethnic and Racial Studies, $38(1), 5-21$.

Joppke, C., \& Morawska, E. (2003). Toward assimilation and citizenship: immigrants in liberal nation-states. Basingstoke: Palgrave Macmillan.

Kaltmeier, O. (2011). The Use of Ethnicity in the Imagineering of Urban Landscapes. In O. Kaltmeier (Ed.), Selling Ethnicity: Urban cultural Politics in the Americas from the conquest to contemporary consumer societies, (pp. 91-94). Surrey and Burlington: Ashgate. 
Korteweg, A. (2017). The failures of 'immigrant integration': The gendered racialized production of non-belonging. Migration Studies, 5(3), 428-444.

Lefebvre, H. (1968). Le droit a la ville [The right to the city]. Paris: Anthropos.

Mahnig, H. (2001). Die Debatte um die Eingliederung von Migranten oder: was ist das Ziel von "Integrationspolitik" in liberalen Demokratien? [The debate about the incorporation of migrants or: what is the goal of 'integration policy' in liberal democracies?]. Swiss Political Science Review, 7(2), 124-130.

Menz, G. (2013). The neoliberalized state and the growth of the migration industry. In T. Gammeltoft-Hansen, \& N. Nyberg Sorensen (Eds.), The migration industry and the commercialization of international migration, (pp. 108-127). London and New York: Routlegde.

Penninx, R. (2009). Decentralising integration policies: Managing migration in cities, regions and localities. Policy network paper. London: Policy Network. Retrieved from http://www.integratingcities2012.eu/documents/(2009\%20\%20Penninx)\%20Decentralising\%20integration\%20policies.pdf.

Rooduijn, M., \& Burgoon, B. (2017). The paradox of wellbeing: Do unfavorable socioeconomic and sociocultural contexts deepen or dampen radical left and right voting among the less well-off? Comparative Political Studies. https://doi.org/10 $1177 / 0010414017720707$.

Sayad, A. (2004). The suffering of the immigrant. Cambridge: Cambridge University Press.

Schinkel, W. (2018). Against 'immigrant integration': For an end to neocolonial knowledge production. Comparative Migration Studies, 6. https://doi.org/10.1186/s40878-018-0095-1.

Soehl, T. (2008). Ethnic Difference and Scale. Locating the City. Paper produced for the "Urban Conflicts, Identities and Architecture". Workshop at the Irmgard Coninx Foundation. Retrieved from http:/www.irmgard-coninx-stiftung.de/128 html.

Thouez, C. (2018). Strengthening migration governance: the UN as 'wingman'. Journal of Ethnic and Migration Studies. https:/ doi.org/10.1080/1369183X.2018.1441604.

Vertovec, S. (1996). Berlin Multikulti. Germany, foreigners and "world-openness". New Community, 22(3), 381-399.

Vertovec, S., \& Wessendorf, S. (2010). The multiculturalism backlash: European discourses, policies, and practices. London: Routledge.

Waters, R. (2018). Integration or black power? The Political Quarterly. https://doi.org/10.1111/1467-923X.12543.

Zapata-Barrero, R., Caponio, T., \& Scholten, P. (2017). Theorizing the 'local turn' in a multi-level governance framework of analysis: a case study in immigrant policies. International Review of Administrative Sciences, 38(2), 241-246.

\section{Submit your manuscript to a SpringerOpen ${ }^{\circ}$ journal and benefit from:}

- Convenient online submission

- Rigorous peer review

- Open access: articles freely available online

High visibility within the field

- Retaining the copyright to your article

Submit your next manuscript at $\boldsymbol{\nabla}$ springeropen.com 